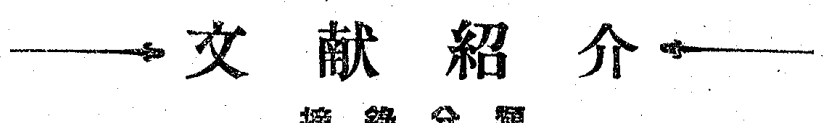

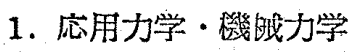
8. 内燃機関
15. 䁔冾房・冷海
2. 工業材料 ·材料学
9. 航空機 - 航空発䵣機
10. 自動事・自動車機関
11. 鉄道・鉄道車两
16. 機構・自動制御・機钱 要紊
4. 䓡. 繁力学
12. 船船 - 舵用穖関
17. 工作機諓・工作法
5. 然料. 然焼
13. 流体力学. 水力機栈
18. 鋳造・鉔造・プレス。 路接
6. 蒸気発生装置
14. 压縮機・送風機
19. 起重機・運搬機
20. 紡織
21. 化学機械
22. 製造・水應機制
23. 土木機战・鉱山機触
24. 工場管理 - 䋊济
25. 工業敎育
26. 杂倠

\title{
1. 応用力学および機械力学
}

$539.431 .015 .2: 669.14$

[55]痤れ寿命汶対する表面あらさの影響乙試験結

果のばらつき [P. G. Fluck, Am. Soc. Test. Mat., Proc., 1951,Vol. 51, p. 584 592, 困 2, 茷 3]

$S-N$ 曲線の傾科部を痕れ寿命と名づけ,この重要性を のベ,ある囚子の疲れ寿命と疲れ限度におよ特す影響 が反対の場合があり，またそ影響の程度も台がうの で，本編では，前者に対する表面あらさの影饗をしら ごている.また寿命のばらつきが最も少さくて,しかも 仕上費用の安いものを見らけるという目的で，同一仕 上の試片各 12 個一組を用いた，材料は㜔なま乙銅 と

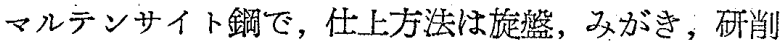
呿よび超仕上など6種類用いている，実験結果から， 研削任上が最もばらつきが少いそ結論しているが，討 論にて Ransom 氏が指摘しているように，試片数が 少く, 統訐的検定も行っていないので疑間の余地はあ る. しかし間題の着眼に注目の洒值はあうう。

[横堀 武夫]

\subsubsection{2 : 539.431.1}

[56] 軸方向圧維疲礼試験 [N. M. Newmark, R. J. Mosbory, W. H. Munse \& R.E. Elling, Am. Soc. Test. Mat., 1951, Vol. 51, p. 792 810, 図 12, 表

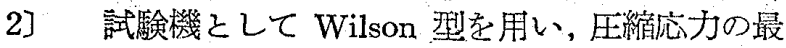
小值を 1000 psi に保っている。試片内のひずるの分 布をひずみ計で測定し，応力が断面に注とんど均一に 分布していることをたしかめている、材料として靕鉄，

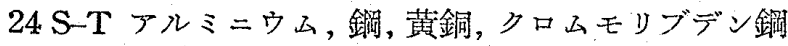
を用い $N-S$ 曲線は前 2 者梳けについて求めた予備実 験的なすのであるが，上のすべての材料について圧緶 のオが马涱り，曲げ疲れ限庋より高いこと，路よびこ の差は軟鋼では他上り大きいといらことな゙けは結論で き,他の研究者による压縮疲れ限度の低い值は残留沁 力, 応力集中あるい渮需応力が䉼面で均一でないこ とによると思われるといっている，討論にて Almen 氏は繰返し压䌉荷重の下で呿こる局部的降伏が残留引! 張応力を生し，とれに上って破壊するのではないかと

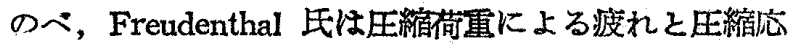
カに上る疲れを区別すべき炕といっている。

\section{[霣场 武夫]}

\subsection{6 : 539.4 .014}

[57] レオトロビックぜレ性 (一般的挙䧽) [E. J. Ripling \& W. M.Baldwin, Jr, Am. Soc. Test. Mat., Proc., 1951, Vol. 51, p. 1023 1037, 困 13]
者達はさきに鍓に抬ける rheotropism 妾報告してい るが, 本編ではこの現象が遷移温度をしめす材料につ。 いての一般的性質であるかどうがたしかめ，レオト ロピックぜい性(1)の基本的性質に関する資料を得るた めの笑験を行っている，要移温度が高いことと高純度 が得られるという点で Zn 妾用いている。実験の結果 rheotropism は低温によって路こるぜい性のみに限ら れたものではなく高ひず多速度に扔けるぜい性もレオ トロピックであることを示している，切欠鐧のぜい性 が最近レオトロピックであるこそがわかったので，温 度, ひず夕速度，応力状態に上って呿こるぜい性がひ ず夕钽感性のものであると考えられると述べている。

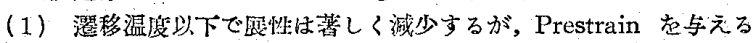

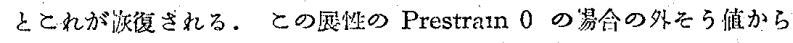

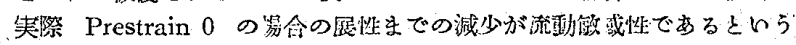
意味でレオトロピツクぜい性とよ犾れている。

[横堀 武夫]

$539.376: 669.5$

[58]一定広力下の亞鉛の流動 - [A.H. Cottrell \& V. Aytekin, Inst. Metals, J., Vol. 77, 1950, p. 339 -422, 図 22, 表 6] 第一編では一定応力下の亜鉛 のクリープ実験を行い，特別の湯合以外はクリープひ ず夕時間曲線が遷移むよび定常クリープに分けられる こと, 前喤が Andrade の $t^{1 / 3}$ 式に従らこと，定常ク リープ速度が $C e-\frac{Q\left(\tau_{0}\right)+b \tau_{0}}{R T} e \frac{b T}{R T}$ なる策虑式で表わさ れることをしめし，また単結晶のクリープはすべりに よるが多結晶では少くともすべり，双晶 cell の形成， 粒界のすべりの 4 過程を含んでいることをしめし，両 者の場合の比較によって得るところは少いのではない 㚈ら見解表表わしている。第二編では単結晶の定 常クリープの理論を発展させている. 固定障壁理論と 恢復理諭との結合理論を提案し，濞いた恢復の関係式 が洃復の垁験そ一致し，式中の活性化エネルギその他 のパラメータがクリープの寒験式のそれと一致するこ そをしめしている，現象論であるが定常クリープをび ずみ硬化と恢復といら二つの過程に分離できるといら 点に特長がある。

[橫㻕 武夫]

$539.4 .011: 669.1-17$

[59] 位の画突 飞铁の降伏 [A. H. Holden, Metals, J, 1952, Vol. 4, p. 182 188, 因 9, 表 1]. Cottrell の鉄の降伏理論はむしろ尖鋭は降伏点の説明

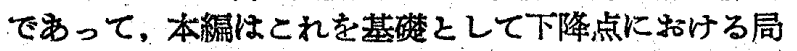

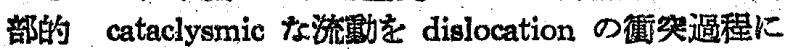

